\title{
"Straszny Dwór" (Haunted Manor) guesthouse in Tatarów in the Hutsul region and its designer Jerzy Romaszkan
}

\author{
Jacek Czubiński \\ e-mail: jacek.czubinski@wp.pl \\ Institute of the History of Architecture, Faculty of Architecture, Cracow University of Technology
}

\begin{abstract}
In the touristic and spa village of Tatarów in the Hutsul region, a very interesting guesthouse called "Straszny Dwór" (Haunted Manor) was established in the late 1930s. Jerzy Romaszkan - artist and amateur architect from Lviv was its designer. He was also the author of two other buildings: his own house and the house of Karol Kossak. Otton Liphardt, merchant from Warsaw, was the investor of "Straszny Dwór". The building distinguishes itself in the region with its specific structure and composition of the façade. Its style refers among others to English Victorian-style and Cottage-style manors and the idea behind it is close to the assumptions of the Arts and Crafts movement.
\end{abstract}

Key words: spa architecture, history of architecture, Hutsul region, Jerzy Romaszkan, Straszny Dwór (Haunted Manor), Tatarów

\section{Introduction}

In a small touristic and spa village of Tatarów, located in the valley of the Prut River in the Hutsul region, a little known, but very interesting building called "Straszny Dwór" (Haunted Manor) is located. It was established at the very end of the 1930s as an exclusive guesthouse. The architecture of this facility, together with the history of its construction, its owner and designer as well as the people connected with it and its history are intertwined with each other, adding to its supra-local meaning. The guesthouse is strictly connected with the history of several families important for the culture, economy and history of Galicia and the Second Polish Republic. These are the Galician Mikolasch, Romaszkan and Kossak families as well as Lilpop and Wedel families from Warsaw. The aim of the paper is to present the history, analyze and try to define the origin of the creation of the "Straszny Dwór" (Haunted Manor) guesthouse in the context of architectural activity of Jerzy Romaszkan, its founder.

Tatarów was developing as a touristic place in a less dynamic way than famous spa resorts Worochta, Jaremcze and Mikuliczyn, situated at the distance of a dozen kilometers to the North and South. In 1910, as one of the first in the valley of the Prut River, an all-year spa resort center was established, managed by Dr. Romuald Sas Żurakowski [Przewodnik..., p. 198]. In the late 1920s, two big sanatoria were constructed - Policyjny Dom Zdrowia (Policemen's Health Center) as well as "Znicz" Railwayman House. Thanks to its peripheral location, Tatarów constituted some kind of the "oasis of peace" with relation to the abovementioned spa centers. This was among others the reason for choosing this village by two famous Lviv families, Mikolasch and Romaszkan, as the location of their summer houses outside the city.

\section{Jerzy Romaszkan}

The persona of Jerzy Romaszkan is going to be quoted in the article many times. He was the designer of both the "Straszny Dwór" guesthouse as well as Kossak's (guest)house "Teresa" together with his own house. They were all located in Tatarów. It should be emphasized that even if Romaszkan had not been educated as an 
architect, his architectural creations were characterized by exceptional professionalism. He was also involved in painting, literature and music. Composer and pianist Roman Jasiński, Romaszkan's friend, characterized this extraordinary persona as follows": "He was (...) the kind of man whose mind, artistic sensitivity and lifestyle formed a whole full of unusual charm. He was not the man of our era. I used to have the impression that he was a noble artist from Liszt's and Chopin's times who accidentally found himself in the present. Jerzy would never come down to earth enough to take up any gainful employment, he was the artist in every inch, and the very much old-style one, gentle, noble, sensitive and sophisticated. But those who would consider him a little lachrymose and sentimental would be wrong. With all his gentleness, he was hiding something wild. And that applied to his appearance as well. Extremely skinny, rather tall, pale face, sharply defined nose, narrow and tightly closed mouth, jet-black hair - this is Jerzy's image, uniting the appearances of Mephisto with his nature, in fact soft and fragile. He drew perfectly well, translated Rilke's poems, played the piano not so bad and above all, had extraordinary architectural skills. Two houses erected by him in Tatarów constituted the symbols of good taste, elegance and perfectly thought-out functionality." [Jasiński, p. 583-584].

\section{Kossak's guesthouse "Teresa" - Mikolasch and Kossak families}

The Mikolasch family inscribed very deeply into the history of the city of Lviv. Piotr Mikolasch was the founder of the "Pod Złotym Orłem" (Under the Golden Eagle) pharmacy in Lviv, in which Ignacy Łukasiewicz together with Jan Zeh performed in 1853 the first distillation of petroleum in the world. In the late $19^{\text {th }}$ century, the Mikolasch were also the investors of the famous Lviv "Mikolasch Passage", which constituted an exceptional undertaking at that time. Under a glass roof, commercial street was established, including shops, cafés as well as a cinema hall. The next from the family, Henryk, in turn inscribed himself in the history of Polish photography as both an exceptional artistic photographer as well as an academic teaching at the Lviv University of Technology as well as the author of a number of publications connected with photography.

In Tatarów, the Mikolasch were in possession of a number of plots of land, used mainly in the summer period, and including houses which belonged to different family members ${ }^{2}$. One of them, situated on the left bank of the Prut River, was purchased by Karol Kossak and his wife Wanda ${ }^{3}$. Ewa, Wanda's mother, was née Mikolasch. The Kossaks decided to build the "Teresa" guesthouse there, referring with its name to their daughter ${ }^{4}$. Jerzy Romaszkan was the designer of this facility. The Kossak family moved there in 1936 and ran the guesthouse until 1943, when accidentally set fire ravaged the building. It was a wooden two-level facility, founded on a stone plinth, with a steep shingled gable roof [Kossak, p. 38]. After the fire, the Kossak family moved to the then General Government in order to finally settle in Ciechocinek, where Karol Kossak died in 1975.

"Teresa" guesthouse was located on a small escarpment of the Prut River. Part of the parcel was situated directly by the river and its remaining part was adjacent to the street. The ground floor of the building hosted rooms used by the owners, including Kossak's bedrooms, as well as those accessible to the guests. On the first floor, rooms for rent were situated. Teresa Kossak, Karol and Wanda's daughter, describes the interiors of the house as follows: "From the side of the street, the house had two entrances: one with the stairs and a small veranda, the second to the kitchen. Main entrance led to a vast hall: there was a big and bright rectangular space serving the function of the living room; Karol's study could also be found there. Right wall was filled with a Venetian window, on the left one could find two doors leading to children's bedroom and the hall, separated with a flat fireplace. In front of the entrance, there was the host's study (...) Karol's room was not big. (...) The window of the room overlooked the Prut River, mountains behind it and the Liszniów polonyna. On the slope, on the clearing which was the best visible from the window, wolves howled in the winter and deer roared in the spring; Gorgany could be seen at the distance. There was a corridor leading from the hall to the vestibule through the kitchen door. There was a bathroom, a kitchen and a larder on the right, while on the left - the room where Wanda and

1 Roman Jasiński was among others the friend of Witkacy, they were immortalized on famous grotesque photographs performed in Jan Kwiatkowski's flat at Wiejska Street in Warsaw. After the war he was among others the Music Redactor of Polish Radio.

2 The already mentioned Henryk Mikolasch died in one of them in 1931.

3 Karol Kossak was Jerzy Kossak's cousin and Wojciech Kossak's nephew.

4 At the current stage of research it has unfortunately been impossible to determine exact location of the facility. Its historical iconography remains unknown as well as. 
the child lived. (...) On the first floor, there were guest rooms with the bathroom and above them - the attic. (...) The interior was modest and modern, but not extravagant." [Jasiński, p. 38-43].

\section{The Romaszkan, Lilpop and Wedel families; Jerzy Romaszkan's own house}

The Romaszkan family was related to the Mikolasch family. It was an old Armenian family, which in the $19^{\text {th }}$ century was distinguished with the baronial title. One of its representatives, Grzegorz Józef Romaszkan, was in the years 1876-1881 Lviv archbishop of the Armenian rite. The Romaszkan family owned a number of properties in the center of Tatarów. In the villas situated along the high left bank of the Prut River, Jerzy Romaszkan used to reside together with his sister and brother and other relatives [Jasiński, p. 408].

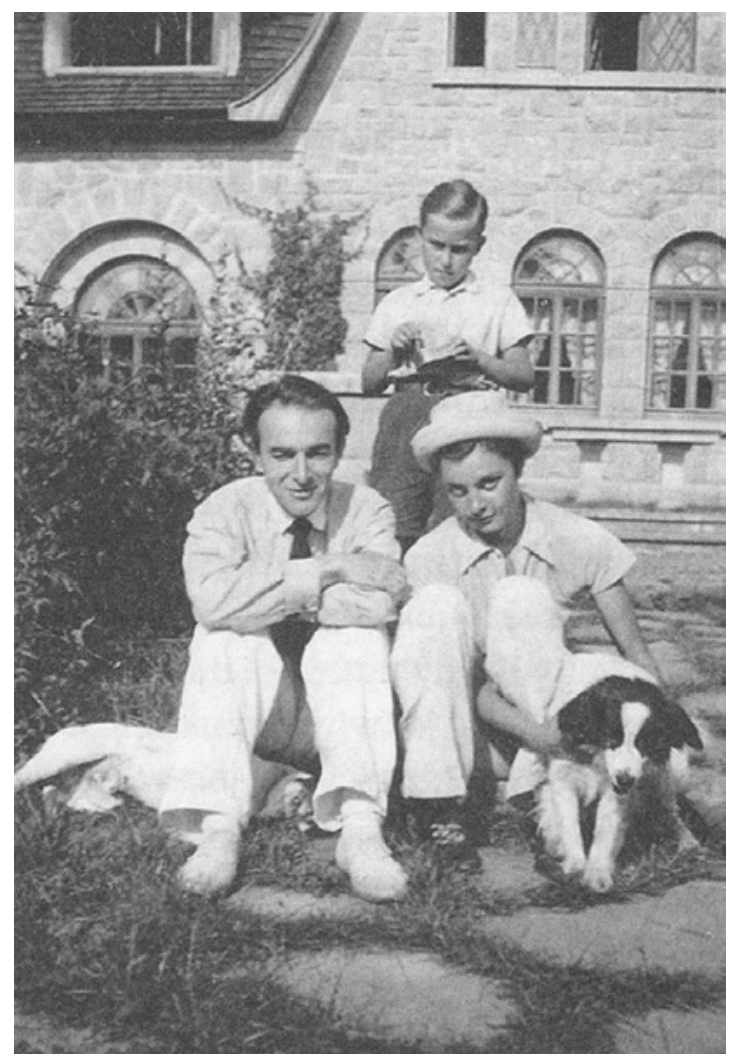

Fig. 1. Tatarów. Jerzy and Alicja Romaszkan, with their son Jan Gaweł. In the background: fragment of the Western façade of the Romaszkan family's house. Photo from the 1930s. Source: [Jasiński, p. 585].

Tatarów. Jerzy i Alicja Romaszkan, z synem Janem Gawłem. W tle fragment elewacji zachodniej domu Romaszkanów. Fot. z lat 30. XX w. Źródło: [Jasiński, s. 585].

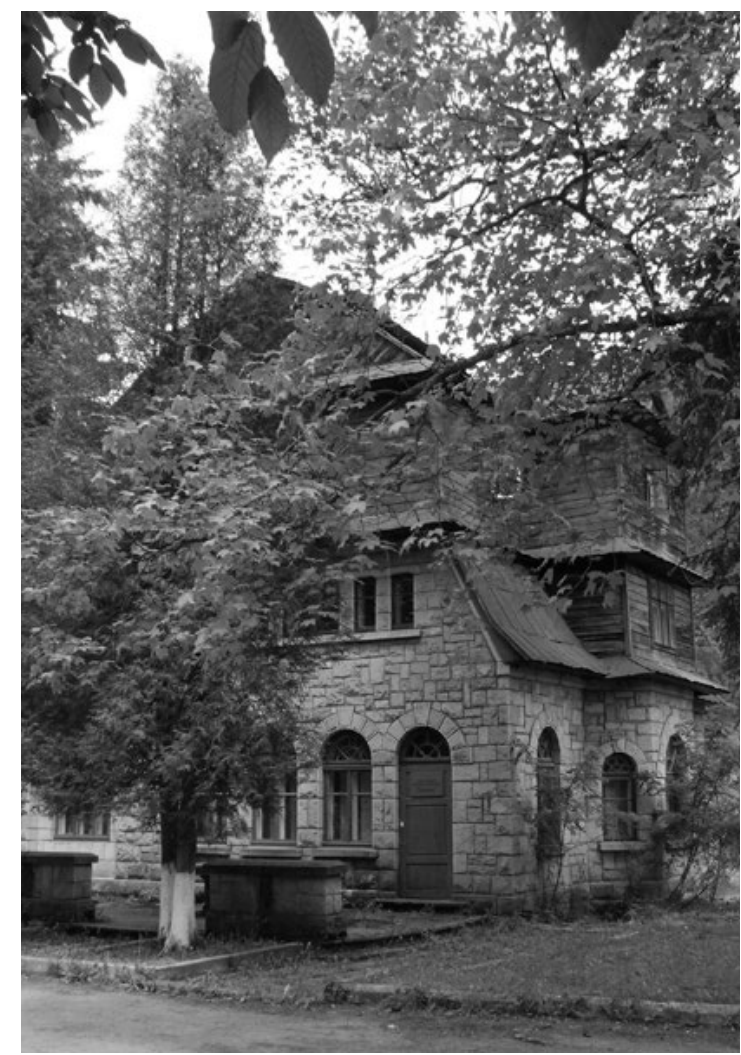

Fig. 2. Tatarów. The Romaszkan family's house, South-Western view, Photo J. Czubiński, 2007.

Tatarów. Dom Romaszkanów, widok od płd.-zach.. Fot. J. Czubiński, 2007.

Jerzy Romaszkan was the author of the design of his own house in Tatarów. It was erected most probably in the late 1920s on a big plot of land, from which the area intended for the construction of "Straszny Dwór" was then separated. Romaszkan suffered from tuberculosis, which was the cause of his frequent stay in Tatarów. He moved there for permanent residence in 1931, having married Alicja Liphardt and they lived there until the outbreak of WW2 [3, p. 581]. Alicja, called Litka by her friends, came from the polonized German family residing for two generations in Warsaw. Her father Otton Liphardt was a rich merchant, who in the inter-war period was among others the representative of the Alsatian Dolfus Mieg \& C company manufacturing threads 
[Jasiński, p. 445-446]. Alicja's mother, Eliza née Vitali, was related to the Wedel family. The Liphardts lived in Warsaw in Wedel's tenement house at 8 Szpitalna Street and Eliza Liphardt was before the war the manager of E. Wedel company shop located in the same building ${ }^{5}$. Jan Wedel was the owner of the company at that time; he was the co-author of the famous construction act from 1933 called Lex Wedel, which served as an impulse for housing investment projects undertaken in the 1930s.

Alicja Liphardt was an extraordinary woman. Extremely intelligent, with many talents and broad artistic interests, she was a commonly recognized persona, appreciated among the elites of the inter-war city of Warsaw. Jerzy Romaszkan got to know her by intermediary of Roman Jasiński. The Romaszkans established in their home in Tatarów a meeting place for the Lviv and Warsaw artistic environment ${ }^{6}$. Numerous famous personas were received there, among others Witold Lutosławski, Józef Wittlin or Zbigniew Uniłowski [Taylor-Terlecka, p. 46].

In September 1939, the Romaszkans travelled to Hungary, where Jerzy died in 1943 and Litka got married again with a Hungarian industrial businessman, earl Charles de Barcza. She was the author of several books, among which Comes the Comrade7, telling the story of the wartime exile, gained international fame. She exchanged correspondence with Stanisław Vincenz concerning the performance of illustrations to the book $\mathrm{Na}$ wysokiej potoninie (On a High Polonyna), which finally did not come true. [Taylor-Terlecka, p.48-49]. After the war, she lived in the USA for a long time and this is from where she came back to Warsaw, where she died in 1973. [Lilpop-Krance, p. 321].

The Romaszkan's house in Tatarów still exists. It is a three-story structure based on the square-like plan with a small avant-corps from the South (photo 2). External walls on the ground floor and partially on the level of the first floor are made of stone and when it comes to higher levels - of timber. The facility is covered with combined pediment and half-gable double curb roof, with a high inter-slope section including the windows of the second story of the building. Initially the building was covered with shingles, but after WW2 they were replaced with flat metal sheets.

On the ground floor level, window and door openings are closed with a semicircular pattern, while on upper levels the pattern is rectangular. Inside, the biggest room forming Romaszkan's study stood out from the remaining part of the house. It was situated in the Eastern part of the building. Big window, taking up almost the entire wall, would open the view of the Prut River. Furniture and interior design were the owner's work. This is how Roman Jasiński, frequent visitor to the house, describes it: "... the house was so beautiful, thin, constructed from stone and wood, standing by a cliff, right next to the Prut River, floating and humming down there. Its interior was modest, but equipped with taste. Robust and solid furniture was mainly tailor-made on site, according to Jurek's drawings, similarly to all fabrics, upholstery, tapestries and blankets. This Hutsul folk works would strike with their beauty and elegance, inventiveness in choosing the colors and reliable performance. (...) A huge attraction (...) consisted for me in good Bechstein's piano standing in Jerzy's room. This wasn't in fact a regular room, but a vast, longitudinal, nearly medieval chamber, with a barrel-like ceiling, dark wood paneling as well as, a little over the level of its floor, a glazed loggia, with a breathtaking view of the Prut River humming down there and a mountain slope covered with thick forest, going up steeply right on its opposite bank..." [Jasiński, p. 584-585].

\section{"Straszny Dwór" guesthouse - Otton Liphardt}

The marriage of Jerzy Romaszkan with Alicja Liphardt together with family connections had a decisive influence on the creation of "Straszny Dwór" guesthouse. At the beginning of their marriage, the relationships between them and Alicja's father, Otton Liphardt, were difficult, they nearly did not maintain any contact. It was changed in the second half of the 1930s, when Alicja's father decided to purchase part of their plot in Tatarów and build the guesthouse there. Jerzy Romaszkan became its designer. Construction works started probably in

5 The fact that "Straszny Dwór" belonged to Otto Liphardt, via the wife related by marriage to the Wedel family, was the reason of false attribution of ownership of this facility to the Wedel family. The author of this article has not managed to avoid this misunderstanding either in [Czubiński 2008, p. 193; Czubiński 2015, p. 76].

6 In the memories of the people visiting this house it was often confused with "Straszny Dwór". For example T. Kossak claims that the Romaszkans moved in 1935 to Straszny Dwór and not to their own house [Kossak, p. 38], while R. Jasiński recalls [Jasiński, p. 676] that "Straszny Dwór" was shingled, while it was the Romaszkans' house which was shingled and "Straszny Dwór" tiled.

7 The book was published under Alexandra Orme artistic pseudonym 
1938 and the building was finished in the spring of the following year. The first and only guests were received in the summer of 1939. Due to the fact that initially planned costs were importantly exceeded, the construction consumed almost all Otton Liphardt's savings. The facility was designed with a great panache and the performance, supervised by the designer himself, was characterized by extraordinary conscientiousness. The guesthouse was initially intended to receive Warsaw elite. During the only season of its functioning, in the summer of 1939, there were aristocrats, diplomats, high-rank state officials and representatives of the world of culture staying there ${ }^{8}$.They all left Tatarów together with the outbreak of the war.
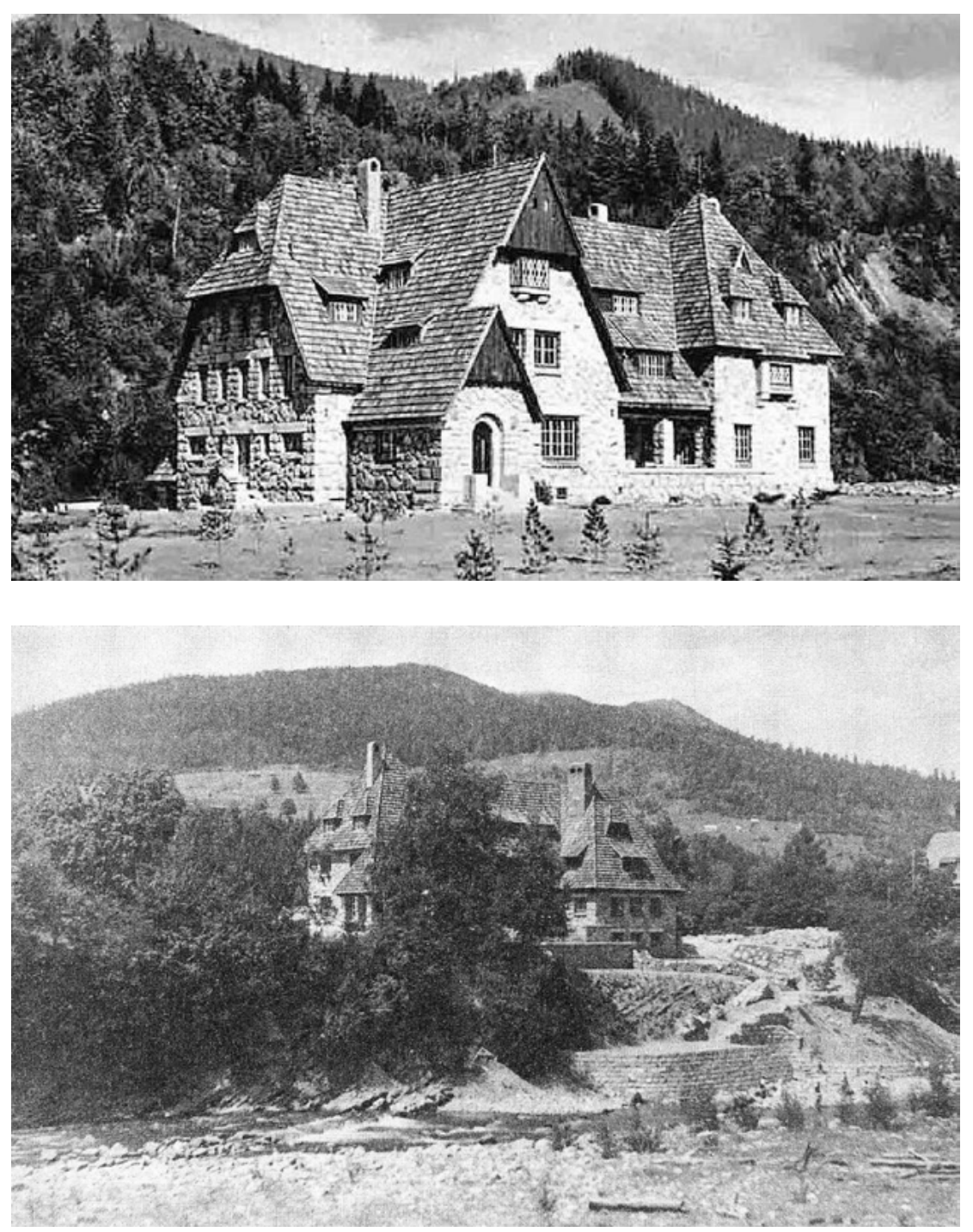

Fig. 3. Tatarów. "Straszny Dwór" guesthouse. North-Western view. Postcard from 1939, from author's collections.

Tatarów. Pensjonat „Straszny Dwór". Widok od płn.-zach. Karta pocztowa z 1939 r., w zbiorach autora.

Fig. 4. Tatarów. "Straszny Dwór" guesthouse. View from the Prut River. Photo from 1939. Source: [Jasiński, p. 678].

Tatarów. Pensjonat „Straszny Dwór". Widok od strony rzeki Prut. Fot. z 1939 r. Źródło: [Jasiński, s. 678].

During WW2, the building hosted the Gestapo seat, thus marking a tragic moment in the history of the Hutsul region. Basements of the facility were transformed into cells as well as the places for tortures and interrogations [Kossak, p. 47; Mazur, p. 112]. After the war, the surroundings of "Straszny Dwór" were connected with the plot of the Romaszkan's house, forming one estate. Ukrainian Academy of Sciences used it until early 1990s. In 2006, the monuments of renowned Russian scientists could still be encountered there, among others the one of Ivan Pavlov. In the 1990s, the facility became private property. 

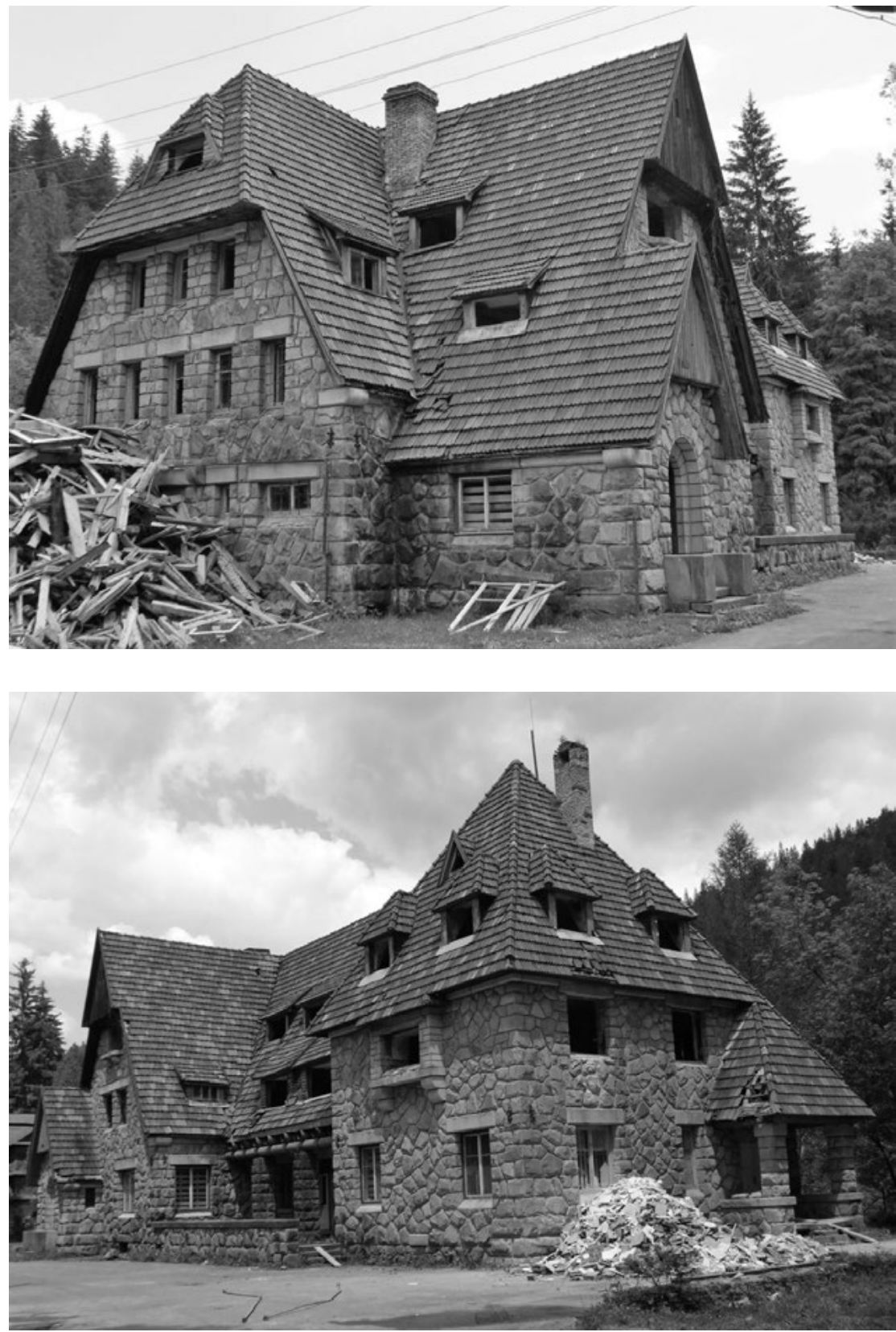

Fig. 5. Tatarów. "Straszny Dwór" guesthouse. North-Western view. Photo J. Czubiński, 2007.

Tatarów. Pensjonat "Straszny Dwór". Widok od płn.-zach. Fot. J. Czubiński, 2007.
Fig. 6. Tatarów. "Straszny Dwór" guesthouse. South-Western view. Photo J. Czubiński, 2007. Photo J. Czubiński, 2012.

Tatarów. Pensjonat "Straszny Dwór". Widok od płd.-zach. Fot. J. Czubiński, 2007. Fot. J. Czubiński, 2012.

The building of former guesthouse is located in the center of Tatarów, by the main road, on the plot the Eastern edge of which is formed by a steep escarpment of the Prut River. From the South, cemetery with a wooden Orthodox Church neighbors it, while from the North, a Roman Catholic chapel dating back to 1911 used to be located. At a small distance from the Western border of the plot, on the opposite side of the mentioned road, railway station constructed in the 1930 s is located.

The property is accessible from the West via the main road leading to the South to Worochta and to the Yablonitsky Pass, and to the North to the target constituted by Stanisławów, via among others Jaremcze, Mikuliczyn and Delatyń. The building is four-story in its majority, five-story in its Northern part, with basements having the stone-timber structure and high multi-slope tiled roof (Fig. 3$)^{9}$. External walls of the basement, ground floor and partially of the first floor have multi-layer structure, from the outside formed by irregular stone ash- 
lars, while brick is present from the inside. Partition walls of these stories are in majority made of brick. Upper stories were performed as timber ones with post-based construction. Ceilings over the basement and ground floor are of reinforced concrete, while on upper stories they have timber structure.

The building is located in a small park situated directly by the Prut River escarpment. Several meters of level difference between the water surface and the facility's ground floor were overcome with the use of stone stairs and terraces, picturesquely going down to the beach by the river (Fig. 4.). The plan of the building is based on an irregular rectangle with avant-corps, located with its longer side in parallel to the Prut River. Main entrance from the park in Western façade leads to the interior of the facility through the terrace as well as deep-seated portico with two pillars. In the North-Western corner, the second entrance is located, while household entrances are located in the Northern façade, with one of them leading directly to the basements (Fig. 5, 6). In the Eastern façade, from the side of the Prut River, exits to the terraces are situated. South-Eastern corner of the building hosts a porch. Southern part of the ground floor level used to include publicly accessible rooms (vestibule, dining room, play room, smoking room). The kitchen section, together with its background, was located in the North. Basements served the functions of household maintenance. Vertical communication used to be ensured by two multi-directional staircases situated on both sides of the entrance hall joined only the ground floor and basement levels. The second used to ensure the connection between all levels of the building.

On upper stories, guest rooms were situated. The Southern and Northern part of the first and second floor was occupied by the suites, while the arrangement of the central section relied on the corridor with rooms from the West.

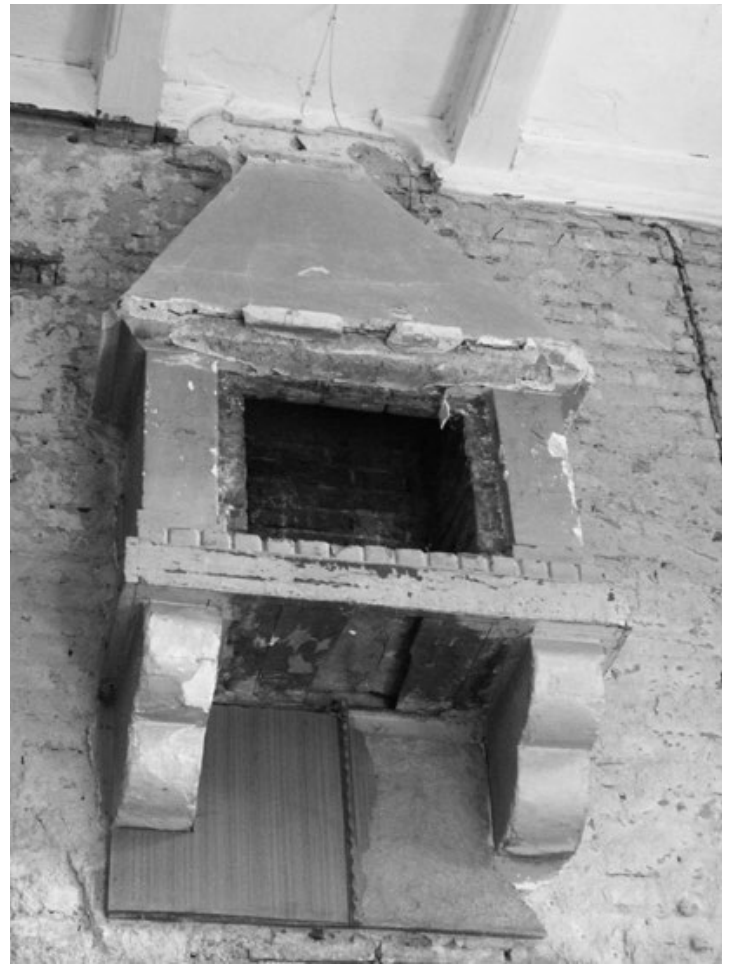

Fig. 7. Tatarów. "Straszny Dwór" guesthouse. Southern avant-corps, fireplace in the level of the first floor. Photo J. Czubiński, 2012.

Tatarów. Pensjonat „Straszny Dwór". Ryzalit południowy, kominek w kondygnacji I piętra. Fot. J. Czubiński, 2012.

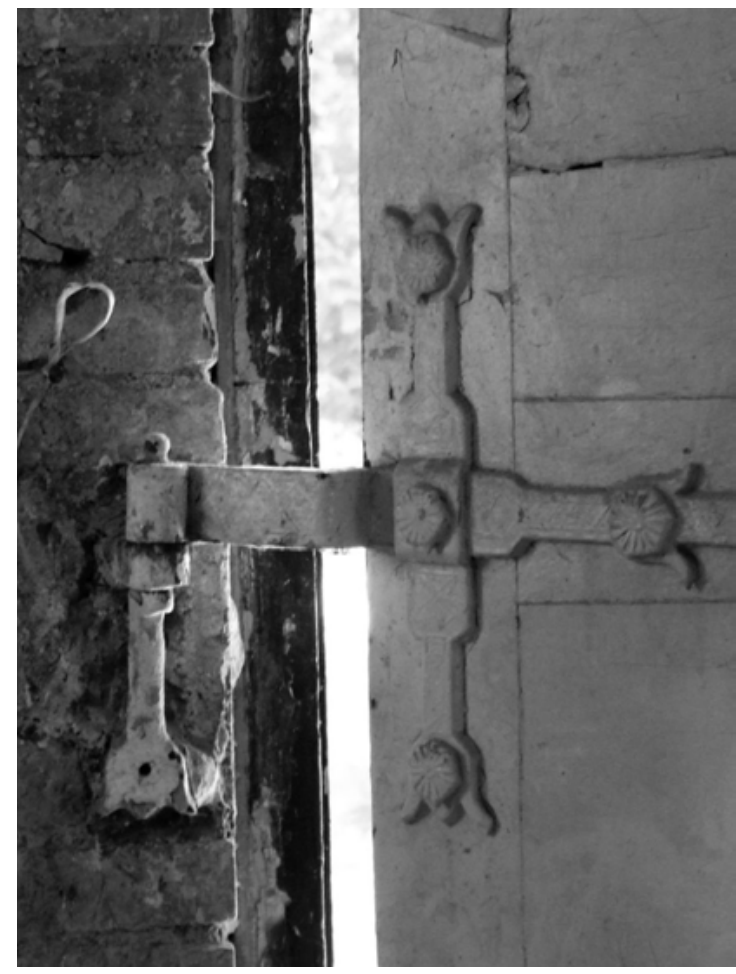

Fig. 8. Tatarów. "Straszny Dwór" guesthouse. Detail of the entrance door fitting in the Western façade. Photo J. Czubiński, 2012.

Tatarów. Pensjonat "Straszny Dwór". Detal okucia drzwi wejściowych w elewacji zachodniej. Fot. J. Czubiński, 2012.

Façades of the building were composed in a particularly interesting way, and none of them is based on the principle of symmetry. Western façade has narrower central part with main entrance, flanked with two asymmetrical avant-corpses. The shape of the Northern one refers to a sharp gable with a smaller entrance avant-corps, 
also having the form of a gable. Both gables are finished in their upper part with vertical boarding. Southern avant-corps is covered with hip roof. Two types of dormers can be found on the roofs: both those finished with cone roofs as well as with hip roofs, resembling regional Podhale highlanders' form called wygledy. On the façades of both avant-corpses, cantilever window protrusions can be found. The Northern one was performed from timber and based on trapezoid plan. Northern façade is finished by a felled gable with pediment roof. In the Western façade, from the side of the Prut River, a large terrace connected with the arrangement of outdoor stairs with the beach by the river constituted the central element. Door openings and windows in stone walls are rectangular, only the entrance in the Northern avant-corps of the Western façade is closed with a semi-circle. Roman Jasiński ${ }^{10}$, visiting the neighboring house of the Romaszkan family in the summer of 1939, knew the "Straszny Dwór" guesthouse from his own experience. This is how he describes it in his post-war memories: "Straszny Dwór" was probably one of the most beautiful buildings in Poland erected in those pre-war times. The most beautiful and solid. It could seem that Jerzy Romaszkan put his entire soul and heart into this work of art. [...] Wall lines, constructed from beautifully arranged huge stones, wriggled capriciously, revealing from all sides the façades composed in different ways. [...] the entire construction was noble and monumental, like some mountain shelter or hunters' castle. It at the same time perfectly matched the surrounding landscape." [Jasiński, p. 676].

The interiors of "Straszny Dwór" also represented a unique character. Their distinguishing elements included among others profiled, polychromed ceiling beams, made of reinforced concrete at the ground floor level and timber on upper levels, fireplaces in the suites of the Southern part as well as details together with their equipment, conscientiously designed or chosen by Romaszkan. This is how Jasiński describes the interiors "The interior of the house was in harmony with its external look. Rustic style prevailed there, with not exaggerated simplicity, attention paid to convenience, elegance and above all coziness, usually absent in new houses built in our region in the new era. One could not find there two rooms which would resemble one another; each of them was individually thought-out and composed, bedrooms, fireplaces, protrusions, beamed ceilings added some special, old-style charm to this place. The furniture was prepared on site, solid and quite heavy, comfortable, respecting the Hutsul style, covered with beautiful and colorful homespun fabrics with charming patterns, and on the floors one could find folk woolen Hutsul blankets "liżiki" in gentle colors. It all added to a very harmonious effect. There were not many of such original and at the same time carefully and conscientiously thought-out interiors in Poland, not to mention guesthouses, usually furnished in a very stereotypical way" [Jasiński, p. 676-677]. It is necessary to emphasize that the furniture and accessories designed by Romaszkan were performed by local artisans.

\section{Origins of the architecture of "Straszny Dwór"}

The analyzed building, among others due to its look and size uncommon in the Hutsul region, was called "Straszny Dwór"11. It is necessary to remember that the architecture of spa and tourism centers in the Hutsul region was in the vast majority constituted by limited-scale timber architecture. The discussed building would not follow that principle in any way ${ }^{12}$. Its architecture was not connected with the tradition of regional forms, it also differed from the trend of modernistic functionalism, present in this region already from the late $1920 \mathrm{~s}^{13}$, and abundantly represented in the late 1930s. Formal expression of "Straszny Dwór" is unique in that region and no analogy to it can be found there. It seems that while designing this guesthouse, Jerzy Romaszkan based on the models dating back to $19^{\text {th }}$ - and $20^{\text {th }}$-century English and American architecture. Philip Webb's and William Morris's "Red House" may constitute distant genesis, together with the ideas of the "Arts and Crafts" movement. This association emerges in particular when we take into account the unity of architecture and interior equipment in the context of the originality and uniqueness of their designing. Personalized approach to

10 Roman Jasiński was the son-in-law of Otton Liphardt, owner of "Straszny Dwór".

11 A local legend emerged in the post-war times that the name dates back to WW2, when the building hosted Gestapo seat. This assumption is not true, which can be proved by the postcard from 1939 with the view of the building and the caption "Straszny Dwór".

12 Stone structure of external walls was in the Hutsul region present in only one more building, which was the seat of the Hutsul Museum in Żabie. The Museum, erected according to the design by Stefan Ohla from the years 1935-1938, was opened in 1938. The building was destroyed at the turn of the 1940s and 1950s. [Pszczółkowski, p. 240-242].

13 Jewish Academics sanatorium should be considered the first building connected with modernism in the Prut valley in the Hutsul region erected in Worochta according to the design as of 1926 by Józef Ewin from Lviv. 
interior arrangement and artisanal conscientiousness of their performance brings Jerzy Romaszkan's attitude closer to the already mentioned Morris's and Ruskin's ideas.

But this is not the only analogy. The building is characterized by an eclectic combination of such elements and features as its picturesque form, asymmetrical façades, irregular plan, sharp gables, steep roofs, pillar porticos, protrusions or regional forms. Stone walls made of local material are characteristic here, combined with boarding in the gables of the Western façade. It may all point to the influence of the so called stone and timber architecture trend. The analogies both with Cottage Style as well as Victorian Style together with the entire scope of their compositional and formal principles [Dixon] are visible. It remains open to what extent these were original English patterns and how much was taken from American architecture.
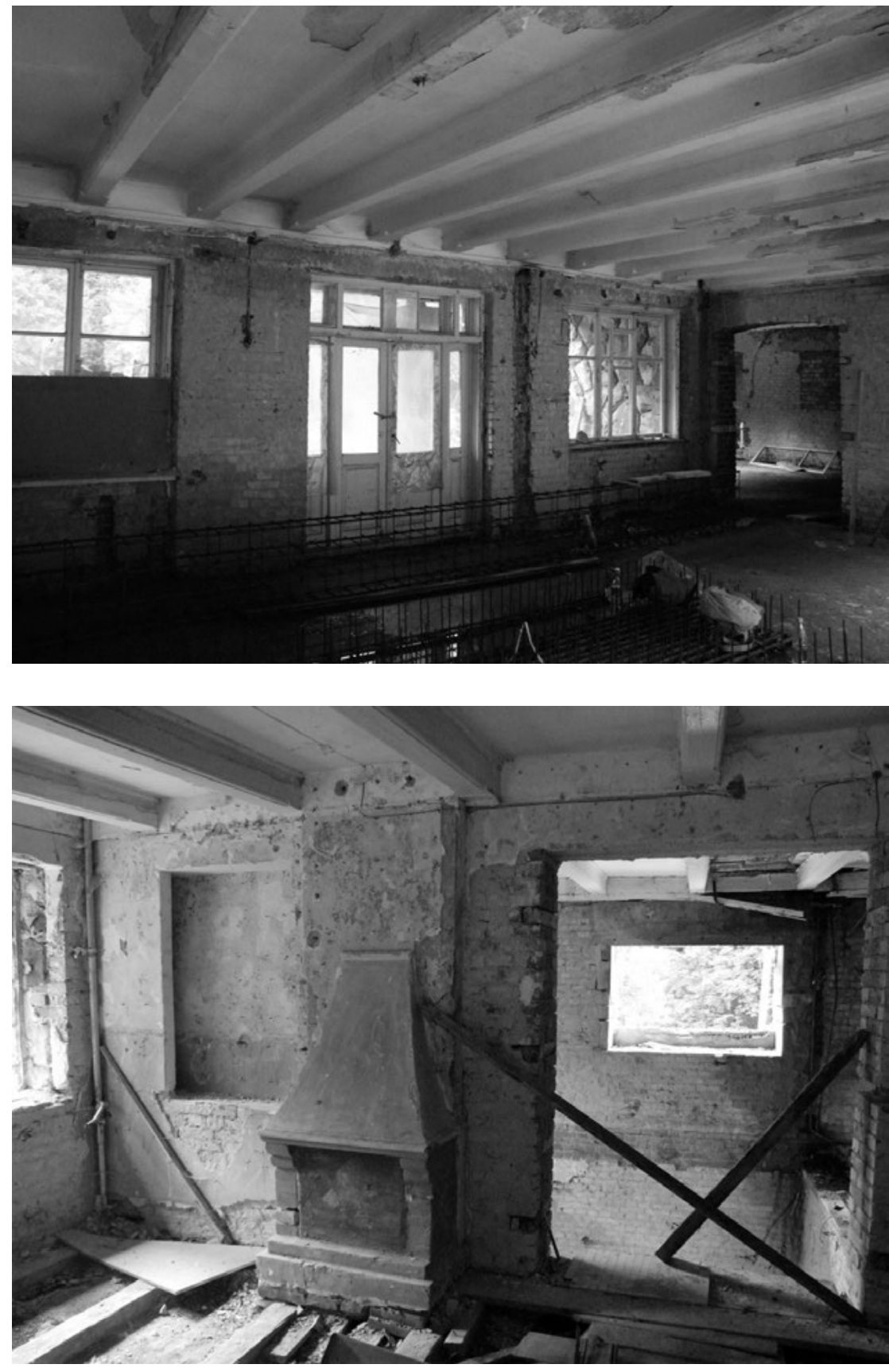

Fig. 9. Tatarów. "Straszny Dwór" guesthouse. Interior of the ground floor, entrance hall. Photo J. Czubiński, 2012.

Tatarów. Pensjonat „Straszny Dwór". Wnętrze kondygnacji parter, hall wejściowy. Fot. J. Czubiński, 2012.
Fig. 10. Tatarów. "Straszny Dwór" guesthouse. Interior of the ground floor, Southern avant-corps. Photo J. Czubiński, 2012.

Tatarów. Pensjonat „Straszny Dwór". Wnętrze kondygnacji parteru, ryzalit południowy. Fot. J. Czubiński, 2012. 
In the architecture of "Straszny Dwór" one can also find the patterns coming from local architecture. It is proved by profiled ceiling beams in the interiors, highlanders' roof form called wyględy or metal door fittings. They include both Hutsul motives as well as those Hutsul-based and borrowed from the Zakopane style.

It is also necessary to notice that this guesthouse, designed ca. 1938, was connected with the trend of stone architecture of mountain shelters established in the Carpathian Mountains in the 1930s. It is exemplified in the Tatra Mountains among others by the "Murowaniec" shelter, and in the Hutsul region by the seat of the Hutsul Museum in Żabie [Czubiński 2008, p. 193].

\section{Summary}

Before the year 2000, the building became private property and its new owners began its renovation. Former house of the Romaszkan family was transformed into a private sanatorium for mothers and their children "Byeryezyna". Its area was surrounded by stone wall with two gates richly ornamented with the elements of blacksmith art. Renovation works consisted in "Straszny Dwór" mainly in demolishing internal walls, removing the ceilings, reconstructing the underground and terrace section in the Eastern part of the facility as well as partially modifying internal walls of the ground floor and the basements. Nevertheless, the works were withheld in 2010. From that time the building, deprived of window frames and with damaged roof, remains abandoned and quickly becomes physically degraded. Today at the verge of technical death, this precious example of inter-war spa architecture of the Hutsul region, seems to be doomed to destruction.

Streszczenie: W miejscowości uzdrowiskowej Tatarów na Huculszczyźnie powstał w końcu lat 30. XX w. niezwykle interesujący pensjonat o nazwie "Straszny Dwór". Jego projektantem był Iwowianin Jerzy Romaszkan - artysta, architekt-amator. Był on także autorem dwóch innych obiektów: domu własnego oraz domu Karola Kossaka. Inwestorem "Strasznego Dworu" był warszawski handlowiec Otton Liphardt. Budynek ten wyróżnia się w regionie specyficzną bryłą i kompozycją elewacji. Stylistyka obiektu nawiązuje m.in. do angielskich rezydencji w typie Victorian oraz Cottage Style a ideowo bliska jest założeniom ruchu Arts and Crafts.

Słowa kluczowe: architektura uzdrowiskowa, historia architektury, Huculszczyzna, Jerzy Romaszkan, Straszny Dwór, Tatarów

\section{Literature}

[1] Czubiński J., Przykłady modernizmu w murowanej architekturze uzdrowiskowej miejscowości Worochta i Tatarów na Huculszczyźnie - zarys problematyki (Examples of modernism in brick spa architecture of the villages of Worochta and Tatarów in the Hutsul region - an outline), Teka Komisji Architektury, Urbanistyki i Studiów Krajobrazowych (Portfolio of the Commission of Architecture, Urban and Landscape Studies), Volume IV A, Polish Academy of Sciences PAN Division in Lublin, Lublin 2008, p. 174-195.

[2] Czubiński J., Rewitalizacja historycznych układów urbanistyczno-architektonicznych w wybranych miejscowościach uzdrowiskowych położonych w dolinie rzeki Prut na Huculszczyźnie (Revitalization of historical urban and architectural arrangements in chosen spa resorts situated in the valley of the Prut River in the Hutsul region), Przestrzeń i forma (Space and Form), Szczecin '23/1 2015, p. 72-84.

[3] Dixon R., Muthesius Stefan, Victorian Architecture, London 1991.

[4] Jasiński R., Zmierzch starego świata, Kraków 2007.

[5] Kossak T., Kossak nieznany, Warszawa 2013.

[6] Lilpop-Krance F., Powroty, Warszawa 2013.

[7] Mazur G., Pokucie w latach drugiej wojny światowej. Położenie ludności, polityka okupantów, działalność podziemia (Pokuttya in the period of WW2. Situation of the people, occupant's policy, underground activity), Kraków 1994. 
[8] Przewodnik po zdrojowiskach i uzdrowiskach polskich (Guide of Polish spa and sanatorium resorts), ed. Z. Pelczar, J. Zanietowski, Kraków 1912.

[9] Pszczółkowski M., Kresy nowoczesne, Łódź 2016.

[10] Taylor-Terlecka N., Nieznane listy Stanisława Vincenza di Alicji de Barcza: zaginiona saga huculska (Unknown letters of Stanisław Vincenz to Alicja de Barcza: a lost Hutsul saga), Conference materials, „Jubileusz Stanisława Vincenza. 120-lecie urodzin"(Stanisław Vincenz's Anniversary. 120 ${ }^{\text {th }}$ Birthday), Kiev 2008, p. 45-50. 